\title{
London in the Global Telecommunication Network of the Nineteenth Century
}

\author{
Roland Wenzlhuemer
}

\begin{abstract}
London is one of the best connected cities in the world - from a structural as well as from a functional perspective. The central finance and business districts of the metropolis feature both an extraordinarily well-developed information infrastructure and an unusually high concentration of information-dependent businesses. Outside these core districts, however, global connectivity drops massively. An informational divide rips through the global city. This paper builds on a comparatively recent understanding of 'new electronic communications technologies as part of a long history of rich and often wayward social practices' (Thrift) and seeks to provide a historical perspective on the emergence of global connectivity patterns. Due to its longstanding history as a global financial centre and its central position in the global and domestic telegraph network of the nineteenth century, London will provide a suitable case study to examine the long-term interplay of socioeconomic and structural patterns in the creation of global information networks.
\end{abstract}

KEYWORDS: telegraph, London, telecommunication, network, submarine telegraphy 


\section{INTRODUCTION - LONDON IN THE GLOBAL INFORMATION NETWORK TODAY}

While London long ago ceded its place as the capital of a world empire, it still and firmly occupies a pivotal position in the global telecommunication network. A recently conducted study on European network connectivity ${ }^{1}$ found that London is the best connected city in Europe regarding the number of bandwidth providers. For the year 2004, London leads the table of 28 evaluated European cities in front of Frankfurt, Paris, Amsterdam and Stockholm. ${ }^{2}$ Going even further than that, Peter Taylor and Rolee Aranya have found that London was actually the world's best connected city in the years 2000 and 2004 in terms of global network connectivity (followed by New York, Hong Kong, Paris, Tokyo and Singapore in both years alike as can be seen in Figure 1). ${ }^{3}$ While Taylor and Aranya also show that in both a global and a national ${ }^{4}$ context other cities feature higher connectivity growth rates than London, the British metropolis still enjoys a comfortable lead in this regard. The first "tale of the networked metropolis" that Stephen Graham and Simon Marvin offer in Splintering Urbanism clearly illustrates London's central position in a worldwide network of global cities, but it also highlights the less known aspect that most of the metropolis' telecommunication systems ${ }^{5}$ centres in and around "the core of central London," where a new optic fibre network has been built. "Only $125 \mathrm{~km}$ long, it carries fully 20 per cent of the whole of the United Kingdom's international telecommunications traffic. [...] However, whilst the cores of global financial

\footnotetext{
${ }^{1}$ If not signified differently, connectivity in this case refers to the degree of access to a global telecommunication network. Depending on the particular context, connectivity can be measured structurally or functionally. In the first case, the degree of connectivity depends mainly on the hardware structure of the network. Is there a direct connection to the network? If so, how many telegraph lines or how much bandwidth can be provided? How fast is the access? Functional connectivity reflects the actual usage of the informational infrastructure. How many messages have actually been sent or how much bandwidth is actually in use? Where are messages sent to? In most cases, functional and structural connectivity correlate closely, but often only one of both can actually be measured due to limits of the existing data.

${ }^{2}$ TeleGeography, "Map of European City Connectivity," Primetrica, Inc., http://www.telegeography.com/ee/free resources/figures/ib-05.php.

${ }^{3}$ Peter Taylor and Rolee Aranya, "A Global 'Urban Roller Coaster'? Connectivity Changes in the World City Network, 2000-04," GaWC Study Group, Loughborough University, http://www.lboro.ac.uk/gawc/rb/rb192.html.

4 _ , "Connectivity and City Revival," Town \& Country Planning 75, no. 11 (2006).

${ }^{5}$ The term telecommunication system should here be read as the communications equivalent of Thomas Hughes' technological system. Accordingly, the term not only encompasses merely technical artefacts or components, but includes labour, management, resources, government regulation etc. as well. A detailed definition of technological systems can be found in Thomas Hughes, "The Evolution of Large Technological Systems," in The Social Construction of Technological Systems, ed. Wiebe Bijker, Thomas Hughes and Trevor Pinch (Cambridge, MA: MIT Press, 1993).
} 
centre spaces reach out to the globe with unprecedented power, increasing efforts are being made to 'filter' their connections with their host cities. In London, for example, the so-called 'ring of steel' supports electronic surveillance systems and armed guards on every entry point into the financial district.",6

Such an isolation of the globally well-connected core emphasises the huge informational integration gaps that have emerged between the central and the peripheral parts of global cities - in this case of London. Beyond the (infra)structural unevenness that has been hinted at in the "tale of the networked metropolis," another study by the Global and World Cities study group at Loughborough University (under whose umbrella Taylor and Aranya conducted their above mentioned survey) has identified current clusters of connectivity in London. Connectivity here is represented by the clustering of financial and related services throughout the metropolis. Based on an impressive empirical survey, the authors found that financial and related services in London exhibit extraordinary concentrations in a number of small municipal locations. A look at the Atlas of Economic Clusters in London, for instance, shows that banks tend to concentrate in two specific spots, in parts of the West End and in the City of London. The latter is a preferred location for most other evaluated business branches as well and emerges as the unrivalled core of financial and related services in London. ${ }^{7}$ Cook et al. have examined the centripetal and centrifugal forces that seek either to perpetuate or to decentralise this concentration. Interviews with senior executives of companies located in the London core revealed that issues such as the reputation and symbolic value of the location as well as the proximity to customers and professional bodies were perceived as the principal benefits of the location. Interestingly, ability to access real-time information on market trends one of the particular advantages of high global connectivity - was seen as a rather unimportant factor. ${ }^{8}$ This suggests that, at least in the case of the longstanding finance and business district in and around the City of London, it is not high infrastructural connectivity that attracts companies. Rather, these businesses create a demand for informational infrastructure that has to be satisfied and instigates a concentration of network structures. Once in place, however, such structures do develop a certain self-sustaining element that further contributes to the conservation of the informational divide.

\footnotetext{
6 Stephen Graham and Simon Marvin, Splintering Urbanism : Networked Infrastructures, Technological Mobilites and the Urban Condition (London: Routledge, 2001)::2

${ }^{7}$ David Walker and Peter Taylor, "Atlas of Economic Clusters in London," GaWC Study Group, Loughborough University, http://www.lboro.ac.uk/gawc/visual/lonatlas.html.

${ }^{8}$ Gary Cook et al., "The Role of Location in Knowledge Creation and Diffusion: Evidence of Centripetal and Centrifugal Forces in the City of London Financial Services Agglomeration," Environment and Planning A 39, no. 6 (2007).:1331
} 
Wenzlhuemer: London in the Global Telecommunication Network of the Nineteenth Century

\begin{tabular}{|c|c|}
\hline Ranks in 2000 & Ranks in 2004 \\
\hline 1. LONDON & 1. LONDON \\
\hline 2. NEW YORK & 2. NEW YORK \\
\hline 3. HONG KONG & 3. HONG KONG \\
\hline 4. PARIS & 4. PARIS \\
\hline 5. TOKYO & 5. TOKYO \\
\hline 6. SINGAPORE & 6. SINGAPORE \\
\hline 7. CHICAGO & 7. TORONTO \\
\hline 8. MILAN & 8. MADRID \\
\hline 9. LOS ANGELES & 9. BRUSSELS \\
\hline 10. TORONTO & 10. FRANKFURT \\
\hline 11. MADRID & 11. AMSTERDAM \\
\hline 12. AMSTERDAM & 12. CHICAGO \\
\hline 13. SYDNEY & 13. MILAN \\
\hline 14. FRANKFURT & 14. SYDNEY \\
\hline 15. BRUSSELS & 15. SAO PAULO \\
\hline 16. SAO PAULO & 16. LOS ANGELES \\
\hline 17. SAN FRANCISCO & 17. ZURICH \\
\hline 18. MEXICO CITY & 18. MEXICO CITY \\
\hline 19. ZURICH & 19. BUENOS AIRES \\
\hline 20. TAIPEI & 20. SAN FRANCISCO \\
\hline
\end{tabular}

Figure 1: Changes in rank among the world's best connected cities, $2000-2004$.

Source: Peter Taylor and Rolee Aranya, "A Global 'Urban Roller Coaster'? Connectivity Changes in the World City Network, 2000-04," GaWC Study Group, Loughborough University, http://www.lboro.ac.uk/gawc/rb/rb192.html.

Technologies usually develop (and are replaced by their successors) less in the form of punctuated equilibria than in a step-by-step evolutionary process. In the case of telecommunication this means that new technologies (think, for instance, of telephony) often use parts of existing technological systems and thereby easily recreate established structural patterns. Therefore, a techno-scape 
(or, more particularly, an info-scape) is not merely the product of a socio-scape (or a finance-scape) ${ }^{9}$ but actually interacts with it.

As Nigel Thrift states: "What is missing from technologically determinist accounts, and what must be re-embedded if we are to understand modern informational spaces and telematic cities, is any concerted sense of new electronic communications technologies as part of a long history of rich and often wayward social practices (including the interpretation of these practices) through which we have become 'socially acquainted' with these technologies."10 Jonathan Rutherford concurs by saying that "the process of developing telecommunications networks and connections is inherently 'social practice' of negotiation and strategic decision-making which is thus bound up with all three levels of [Manuel Castells'] space of flows." 11 These three layers encompass "a circuit of electronic impulses such as telecommunications; a network of place-based nodes and hubs; and the spatial manifestation of dominant groups and interests. [...] Developments in [the] second layer must, of course, subsequently reinfluence those of the third and first layers, as the layers of the space of flows are completely intertwined."12

\section{HISTORICAL DIMENSION}

If we accept this notion that contemporary connectivity patterns are the products of social practices, it becomes important to add a historical dimension to our understanding of "modern informational spaces" in order to learn more about the distinct roles of the different contributing agents and layers in this "extraordinarily complex and dynamic socio-technical process." 13 A number of crucial similarities become visible, when we compare current telecommunication network patterns and practices with their counterparts in the mid-nineteenth century - the time when the first technologically mature telecommunication network emerged. Jonathan Rutherford, for instance, acknowledges one of several historical linkages in the informational development in and around the City of London. He writes: "In London, the congestion of the telegraph network in the 1850 s was associated with the increasing reliance on it of business users and the Stock Exchange to transmit important information. [..] Just as today's business

\footnotetext{
${ }^{9}$ Graham and Marvin, Splintering Urbanism : Networked Infrastructures, Technological Mobilites and the Urban Condition.:8

${ }^{10}$ Nigel Thrift, "New Urban Eras and Old Technological Fears: Reconfiguring the Goodwill of Electronic Things," Urban Studies 33, no. 8 (1996).:1372

11 Jonathan Rutherford, "Networks in Cities, Cities in Networks: Territory and Globalisation Intertwined in Telecommunications Infrastructure Development in Europe," Urban Studies 42, no. $13(2005): 2391$

12 Ibid.:2393

13 Graham and Marvin, Splintering Urbanism : Networked Infrastructures, Technological Mobilites and the Urban Condition.:8
} 
users look for ever quicker and more efficient communication networks, the London Stock Exchange at the time was not going to function unless a way was found to ease congestion on the networks. The solution was the creation of a pneumatic tube system powered by steam engines to transmit messages from the Stock Exchange to the Central Telegraph Office, where they were then telegraphed to their final destination. [...] The way in which this system prioritised, at first, the business market makes it, in many ways, a precursor to the metropolitan fibre optic telecommunications networks of today which are constructed by operators in the key business market." 14

Both in the nineteenth as well as in the twentieth and twenty-first centuries, the high global connectivity of central London is, therefore, a product of comparable business demands. London's status as a global financial centre requires access to a network of global cities. Telecommunication structures build on and reflect underlying social, economic and political structures. That is to say that continuity in economic and political patterns will usually translate itself into the realm of telecommunication, while - on the other hand - sudden changes in the geopolitical or world economic situation will also impact the communication structure. Such interplay of the socio-scape and the info-scape can also be discerned from a more global perspective. A comparison of the two global communication maps depicted in Figures 2 and 3 illustrates this notion.

Figure 2 shows a Chart of the World's Principal International Cables in the year $1924 .{ }^{15}$ It has been compiled by the International Telegraph Bureau in Berne, Switzerland, and is one of the few nineteenth or early twentieth-century telecommunication maps that show not only the cables and wires of one company or nation but sought to include all existing lines. Figure 3 introduces us to the modern telecommunication infrastructure. The Submarine Cable Map 2007 depicts the global pattern of today's telecommunication cable network which carries the bulk of everyday international information exchange (while satellites handle only a tiny fraction of the traffic). ${ }^{16}$ The overall structures of both networks are remarkably similar. Both exhibit an emphasis on transatlantic communication and toward Europe and the North American east coast with crucial positions in the network. Both networks largely bypass the African continent. They attach some more importance to South America while never closely integrating that region into the network. Yet there are remarkable differences as well. East and Southeast Asia have been incorporated into the

\footnotetext{
14 Jonathan Rutherford, A Tale of Two Global Cities : Comparing the Territorialities of Telecommunications Developments in Paris and London (Aldershot: Ashgate, 2004).:80

${ }^{15}$ International Telegraph Bureau, "Chart of the World's Principal International Cables," (Berne: International Telegraph Bureau, 1924).

${ }^{16}$ TeleGeography, "Submarine Cable Map 2007," Primetrica, Inc., http://www.telegeography.com/products/map_cable/index.php.
} 


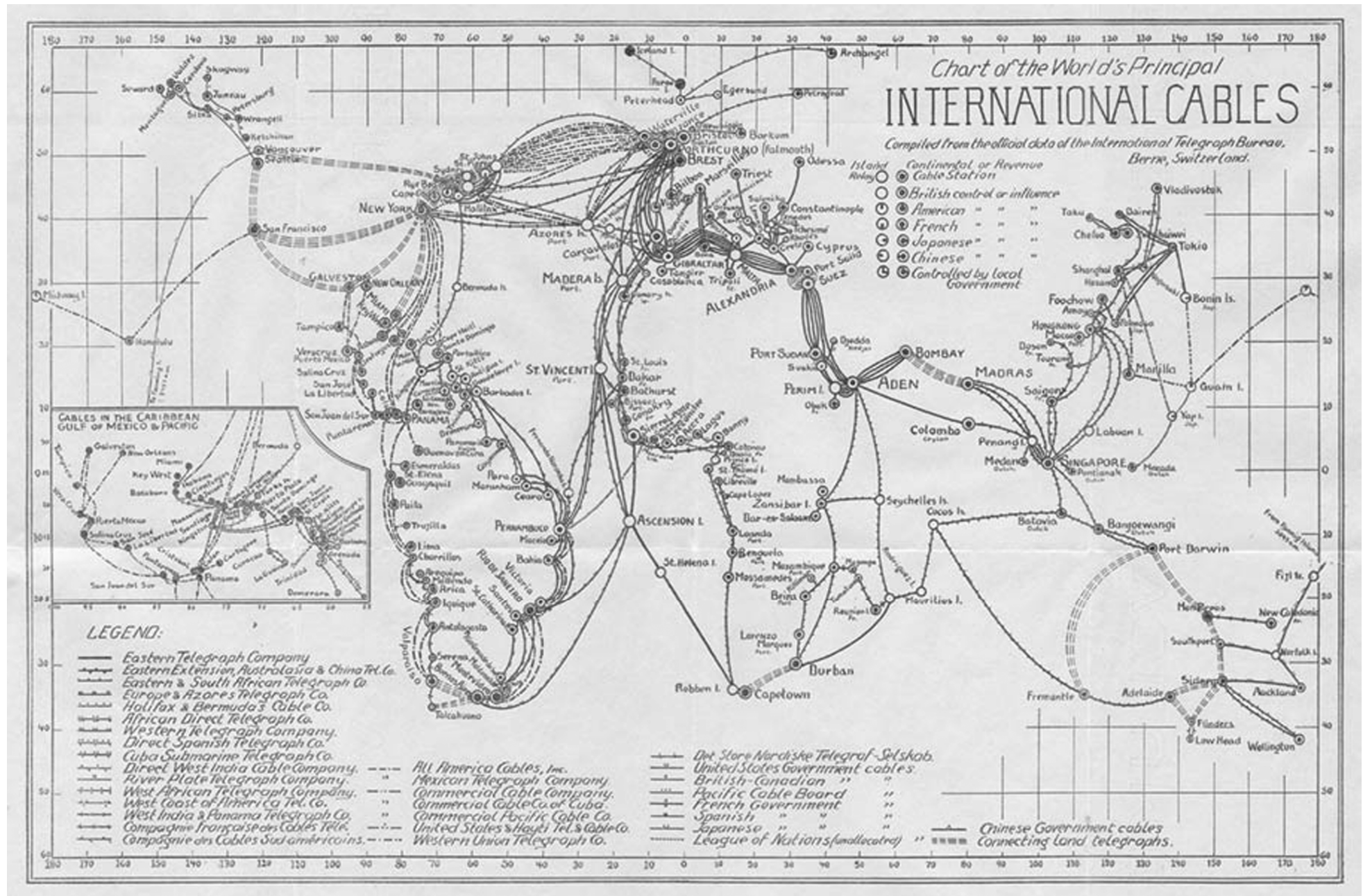

Figure 2: Chart of the World's Principal International Cables 1924.

Source: International Telegraph Bureau, "Chart of the World’s Principal International Cables," (Berne: International Telegraph Bureau, 1924). 
Wenzlhuemer: London in the Global Telecommunication Network of the Nineteenth Century



Figure 3: TeleGeography, Submarine Cable Map 2007 - January 2007.

Source: TeleGeography, Submarine Cable Map 2007, (Primetrica, Inc., 2007).

Published by The Berkeley Electronic Press, 2009 
network structure comparatively tightly during the last couple of decades. Figure 3 shows an impressive cable network around Japan, the Chinese coast and Southeast Asia. While the connection of this economically rising region with Europe (mainly through the Red Sea) is one of long standing, the transpacific link has been massively intensified during the second half of the twentieth century.

The comparison of the two maps neatly illustrates how, as mentioned above, underlying socioeconomic or geopolitical factors impact and indeed shape telecommunication structures. Seen from a zoomed-out, macro-economic perspective, the respective positions of Western Europe, North and South America and Africa in the world economy have witnessed no dramatic shifts since the Chart of the World's Principal International Cables was compiled in 1924. Parts of East and South-East Asia, however, have gone through a thorough socioeconomic transformation ever since, with Japan in the lead, the so-called Tiger states following with some delay and recently with the Chinese economy coming into full swing. This socioeconomic emancipation is very clearly reflected by the current telecommunication network.

These two examples of historical telecommunication systems that are functionally (City of London) and structurally (global network) absolutely comparable to present systems has so far only illustrated how socioeconomic patterns and necessities co-create network structures. And yet there is an impact in the reverse direction as well. The degree of access to a global communication network is, of course, a necessary and attractive feature of a core financial region. And - maybe even more importantly - in reverse, informational logic, underdeveloped regions will fail to attract financial services on a large scale. It is reasonable to assume that this is especially true when both the absolute and the relative time difference in information access between connected and unconnected regions is very big - for instance in the nineteenth-century telegraph network. While we do not yet have statistical evidence to support this claim, an ongoing study on telegraphic connectivity patterns in nineteenth-century Great Britain works with the hypothesis that high and low degrees of telegraphic connectivity crucially impacted the economic development of regions outside London. First tentative evidence as to this has already been obtained in another study that examines the interplay of a region's access to the global telegraph network and its position in global trade flows. While further refinement of the data will be necessary, first results suggest that connecting a region to the global telegraph network (often for entirely different reasons) in several cases triggered changes in the economic system and global export/import patterns.

Network patterns can, indeed, have an impact upon the socioeconomic development of a place. And accordingly it becomes crucial to understand how such patterns are both influenced by their own technological necessities and perpetuated by a certain self-sustaining capability of established network 
structures. First, the limitations or specific requirements of certain technologies impact on network structures. One of many historical examples can be found in the laying of the first transatlantic communication cable in the 1850s and 1860s. This cable connected the town of Valentia in Ireland with Heart's Content in Newfoundland and, thus, promoted two places of little global significance to major telecommunication relay stations. The prime reason for not connecting London and New York directly lay in the technological limitations of nineteenthcentury cable technology. Signal quality weakened and cable integrity worsened with the length of the cable. Therefore, the transatlantic cable traversed the Atlantic at its narrowest possible point and thereby co-established a particular network pattern that should be in place for several decades thereafter.

Second, certain aspects of the economies of networks contribute to the self-perpetuation of patterns and structures. Although so-called technological leaps do occur every now and then and dramatic technological progress can be made in a very short time, most technological change is incremental - at least from a historical perspective. Speaking for telecommunication technology, for instance, the most striking example is the unchanged reliance of global internet communication on cables and wires as its most important vehicles. This has not changed since the early days of telegraphy. While the technology behind wired communication has naturally progressed during the last 170 years, most of the technological advances have been implemented only in a step-by-step fashion. This means that a new technology usually used parts of the same infrastructure, the acknowledged rights-of-way, the trained personnel and the existing technological subsystems that the preceding system had utilized. Therefore, sudden changes in network patterns occur only rarely. If you already have a working relay station, skilled operators and landing rights in place in, say, Valentia, why would you establish a new site somewhere else, if the prospective gain in efficiency was only marginal?

It becomes evident that contemporary global communication patterns can only be understood within their historical context. In the case of modern telecommunication a continuous (albeit not always linear) line of development can be discerned from about the mid-nineteenth century onwards. With the invention and widespread application of electric telegraphy modern telecommunication had developed its essential distinguishing mark: the dematerialization of the information that was communicated. ${ }^{17}$ Dematerialization fundamentally changed the character of long-distance communication and marks an important shift in the history of human communication. And although its

${ }^{17}$ For the significance of dematerialization see Roland Wenzlhuemer, "The Development of Telegraphy, 1870-1900: A European Perspective on a World History Challenge," History Compass 5, no. 5 (2007), — , "The Dematerialization of Telecommunication: Communication Centres and Peripheries in Europe, 1850-1920," Journal of Global History 2, no. 3 (2007). 
pervasion, speed or capacities have dramatically increased ever since, the essential characteristic of telecommunication has not changed since then: the separation of information from material movement. Therefore, the sociotechnological development of telecommunication since the establishment of the first international telegraph network in the nineteenth century forms our historical frame of reference if we want to understand the rationale of today's information societies.

As this article is primarily concerned with examining London's place in the global information network and putting it into a historical perspective, we shall examine Great Britain's overall position in the global telegraph network of the nineteenth century. Second, London's historical connectivity with other cities will be assessed. And finally we will also ask whether nineteenth-century London already featured a similar internal informational divide as it does today.

\section{THE UNITED KINGDOM IN THE GLOBAL INFORMATION NETWORK OF THE NINETEENTH CENTURY}

Due to Great Britain's island status, its international telegraphic connections depended on the laying of submarine cables from the very start. Until this technology had reached a certain maturity in the early 1850s, Britain's external communication relied on material transportation either by ship or - in rarer cases and for selected purposes only - by carrier pigeons. ${ }^{18}$ After a number of experiments with submarine telegraph cables in harbours, between ships or across rivers, the first cable proper was put in place between Dover and Calais in the year 1850. Although the cable only lasted for three days until it was severed by a fishing boat, the feasibility of submarine telegraphy had been demonstrated. Accordingly, the Submarine Telegraph Company gave it a second try and installed another cable in 1851. This time the connection worked satisfactorily and stayed in operation until 1890 - an immensely great time-span given the pace at which submarine cable technology developed during the late nineteenth century. Other Submarine Telegraph Company cables between Britain and France (Boulogne - Folkstone 1852), Britain and Belgium (Oostend - Dover 1853) ${ }^{19}$ and

\footnotetext{
${ }^{18}$ Andrew Odlyzko and Niall Ferguson both refer to the fact that, for instance, the Rothschild family was highly critical of the newly introduced telegraph in the mid-nineteenth century. Through electric communication the Rothschilds were partially losing their critical lead in obtaining up-to-date business information thanks to a network of - amongst other means - carrier pigeons.

Andrew Odlyzko, "History of Communications and Its Implications for the Internet " (AT\&T Labs, 2000).:39-40 Niall Ferguson, The House of Rothschild. The World's Bankers, 1849-1999 (New York: Viking, 1999).:64-65

${ }^{19}$ Bureau International des Administrations Télégraphiques, "Nomenclature Des Cables Formant Le Réseau Sous-Marin De Globe," Journal Télégraphique III, no. 29 (1877).:567
} 
Britain and Germany (Emden - Cromer 1858) followed suit. The Electric \& International Telegraph Company (known simply as the 'Electric') established four cable connections between England and the Netherlands from 1853 to 1855. It also established connections with Ireland and the Channel Islands. The Electric's main competitor, the English \& Irish Magnetic Telegraph Company (known as the 'Magnetic') ${ }^{20}$, laid two long-lived cables between Scotland and Ireland (1853 \& 1854).

Although other - mainly European - countries started to install internal cables as well during the 1850s, the British pioneered the technology and maintained a firm lead in international connectivity. Not only were British companies busily establishing connections with mainland Europe. Jointly, British and American investors very early tried to directly connect the United Kingdom and the United States in 1857. The first attempt failed completely, but a year later a first working connection was put into place. The cable ceased to work after about three weeks, but had enjoyed enough opportunities to prove its political and economic potential during that time. ${ }^{21}$ Accordingly, renewed Anglo-American efforts (epitomised by the jointly founded Anglo-American Telegraph Company) finally installed two fully working cables between Valentia in Ireland and Heart's Content in Newfoundland in 1866. North America and Europe had eventually been brought into direct and lasting telegraphic contact - and the United Kingdom became the first European gatekeeper in transatlantic telecommunication.

In the following decades, the United Kingdom managed to cement its central position in the global telegraph network. The figures in Tables 1 and 2 have been taken from the International Telegraph Bureau's register of submarine telegraph cables - the so-called Nomenclature des Cables Formant le Réseau Sous-Marin $d u$ Globe - and illustrate who owned and worked the world's cables in the year 1877. Table 1 refers to cables and wires owned by governments, while Table 2 lists the overall length of the private companies' cables. Among the listed governments (or administrative departments), the Indo-European Telegraph Department - a department of the administration of British India based in London - worked the longest stretch of cables by far. The French government controls more length of cable than the British, but the latter operates more wires and

\footnotetext{
${ }^{20}$ Through a merger with the British Telegraph Company, the English \& Irish was renamed the British \& Irish Magnetic Telegraph Company in 1857.

${ }^{21}$ Andrew Odlyzko mentions that during its brief spell of stable working, the cable carried a message from the UK to North America that cancelled the scheduled transhipment of British troops from Canada to India. These troops had been ordered to India in order to help in subduing the so-called Indian Mutiny - which had, however, come under control since the sending of the order. Odlyzko says that this particular message saved the crown an estimated amount of $£ 250,000$ and thereby demonstrated the potential of the transatlantic connection. Unfortunately, he does not cite any sources to support this claim.

Odlyzko, "History of Communications and Its Implications for the Internet ".:38
} 
therefore commands higher communication capacities. Most of the other featured administrations lag far behind. The most substantial part of the submarine telegraph network, however, was run by private companies - as can be seen in Table 2. While a big proportion of the governmental cables were so-called internal lines (e.g. traversing lakes and rivers or connecting islands), most of the international traffic went through private lines. The table displays the companies arranged according to their main business seat. Companies with their main seat in London controlled over 88 percent of the total lengths of privately owned cables and wires. Sure enough non-British capital has also been invested in the London companies, but the figures in Table 2 generally support the central role of both Great Britain and its capital in the global submarine telegraph network.

\begin{tabular}{|c|c|c|c|c|c|}
\hline Government & Cables & $\begin{array}{l}\text { Length of } \\
\text { Cable (in } \\
\text { NM) }\end{array}$ & $\begin{array}{l}\text { in } \% \text { of } \\
\text { Total }\end{array}$ & $\begin{array}{l}\text { Length } \\
\text { of Wires } \\
\text { (in NM) }\end{array}$ & $\begin{array}{l}\text { in } \% \text { of } \\
\text { Total }\end{array}$ \\
\hline Austria & 25 & 86 & 1.94 & 97 & 1.69 \\
\hline British India: Indian Administration & 2 & 60 & 1.35 & 60 & 1.05 \\
\hline British India: Indo-European Telegraph Department & 6 & 1,721 & 38.74 & 1,721 & 30.05 \\
\hline Denmark & 29 & 101 & 2.28 & 335 & 5.85 \\
\hline Dutch Indies & 1 & 56 & 1.26 & 56 & 0.98 \\
\hline France & 26 & 673 & 15.15 & 673 & 11.75 \\
\hline Germany & 21 & 149 & 3.36 & 267 & 4.66 \\
\hline Greece & 2 & 4 & 0.08 & 4 & 0.06 \\
\hline Italy & 12 & 218 & 4.92 & 221 & 3.86 \\
\hline Japan & 11 & 72 & 1.61 & 72 & 1.25 \\
\hline Netherlands & 18 & 37 & 0.83 & 55 & 0.96 \\
\hline New Zealand & 1 & 20 & 0.45 & 20 & 0.35 \\
\hline Norway & 1 & 233 & 5.25 & 233 & 4.07 \\
\hline Russia & 3 & 63 & 1.41 & 71 & 1.23 \\
\hline Spain & 6 & 283 & 6.38 & 337 & 5.89 \\
\hline Sweden & 4 & 23 & 0.51 & 23 & 0.39 \\
\hline Turkey & 11 & 143 & 3.22 & 146 & 2.55 \\
\hline United Kingdom & 49 & 501 & 11.27 & 1,338 & 23.36 \\
\hline Total & 228 & 4,442 & 100.00 & 5,727 & 100.00 \\
\hline
\end{tabular}

Table 1. Number and length of governmental submarine telegraph cables, 1877.

Source: Bureau International des Administrations Télégraphiques, "Nomenclature Des Cables Formant Le Réseau Sous-Marin De Globe," Journal Télégraphique III, no. 29 (1877).:576-90. 
Wenzlhuemer: London in the Global Telecommunication Network of the Nineteenth Century

\begin{tabular}{|c|c|c|c|c|c|c|}
\hline Business Seat & Company & Cables & $\begin{array}{l}\text { Length of } \\
\text { Cables } \\
\text { (in NM) }\end{array}$ & $\begin{array}{l}\text { in } \% \text { of } \\
\text { Total }\end{array}$ & $\begin{array}{l}\text { Length } \\
\text { of } \\
\text { Wires } \\
\text { (in } \\
\text { NM) }\end{array}$ & $\begin{array}{l}\text { in } \% \\
\text { of } \\
\text { Total }\end{array}$ \\
\hline \multirow[t]{3}{*}{ Berlin } & Vereinigte Deutsche Telegraphen-Gesellschaft & $2 \vdots$ & 225 & 0.38 & 900 & 1.42 \\
\hline & $\begin{array}{l}\text { Hamburg-Helgolander Telegraphen- } \\
\text { Gesellschaft }\end{array}$ & 1 & 32 & 0.05 & 32 & 0.05 \\
\hline & Berlin total & 3 & 257 & 0.43 & 932 & 1.47 \\
\hline Buenos Aires & River Plate Telegraph Company & $1 \vdots$ & 32 & 0.05 & 64 & 0.10 \\
\hline $\begin{array}{l}\text { Copenhagen (and } \\
\text { London) }\end{array}$ & Great-Northern Telegraph Company & 13 & 4,107 & 6.90 & 4,219 & 6.66 \\
\hline $\begin{array}{l}\text { La Valetta (and } \\
\text { London) }\end{array}$ & Mediterranean Extension Telegraph Company & 3 & 198 & 0.33 & 198 & 0.31 \\
\hline $\begin{array}{l}\text { Lima (and } \\
\text { London) }\end{array}$ & West Coast of America Telegraph Company & 6 & 1,670 & 2.80 & 1,670 & 2.64 \\
\hline \multirow[t]{15}{*}{ London } & Submarine Telegraph Company & 10 & 801 & 1.34 & 3,717 & 5.87 \\
\hline & Scilly Telegraph Company & $1 \vdots$ & 27 & 0.05 & 27 & 0.04 \\
\hline & Direct Spanish Telegraph Company & 3 & 748 & 1.26 & 748 & 1.18 \\
\hline & Black-Sea Telegraph Company & 1 & 365 & 0.61 & 365 & 0.58 \\
\hline & Indo-European Telegraph Company & 1 & 8 & 0.01 & 24 & 0.04 \\
\hline & Eastern Telegraph Company & 39 & 14,503 & 24.35 & 14,548 & 22.97 \\
\hline & $\begin{array}{l}\text { Eastern Extension Australasia and China } \\
\text { Telegraph Company }\end{array}$ & 9 & 7,381 & 12.40 & 7,381 & 11.65 \\
\hline & Anglo-American Telegraph Company & 17 & 12,315 & 20.68 & 12,315 & 19.44 \\
\hline & $\begin{array}{l}\text { Direct United States Cable } \\
\text { Company }\end{array}$ & 2 & 3,040 & 5.11 & 3,040 & 4.80 \\
\hline & Brazilian Submarine Telegraph Company & 3 & 3,866 & 6.49 & 3,866 & 6.10 \\
\hline & Cuba Submarine Telegraph Company & 3 & 940 & 1.58 & 940 & 1.48 \\
\hline & West India and Panama Telegraph Company & 19 & 3,970 & 6.67 & 3,970 & 6.27 \\
\hline & Central American Telegraph Company & 2 & 1,080 & 1.81 & 1,080 & 1.70 \\
\hline & Western and Brazilian Telegraph Company & 9 & 3,750 & 6.30 & 3,750 & 5.92 \\
\hline & London total & 119 & 52,794 & 88.66 & 55,771 & 88.05 \\
\hline New York & International Ocean Telegraph Company & $4 \vdots$ & 490 & 0.82 & 490 & 0.77 \\
\hline Total & & 149 & 59,548 & 100.00 & 63,344 & 100.00 \\
\hline
\end{tabular}

Table 2. Number and length of privately owned submarine telegraph cables, 1877.

Source: Bureau International des Administrations Télégraphiques, "Nomenclature Des Cables Formant Le Réseau Sous-Marin De Globe," Journal Télégraphique III, no. 29 (1877):576-90.

In addition to its excellent external connectivity, the United Kingdom also boasted a very well-developed domestic telegraph network. As I have shown elsewhere, only several comparatively small European countries (such as 
Belgium, the Netherlands or Switzerland) and Germany had internal networks that could compare with the British network in terms of density and capacity. But in terms of actual usage of the network, the United Kingdom significantly outperformed all competitors. In 1890, for instance, it featured a rate of inland telegrams per person almost four times that of Germany. This illustrated that the British domestic telegraph network of the late nineteenth century was also among the tightest and probably the most heavily used in the world. ${ }^{22}$

\section{LONDON’S POSITION IN THE GLOBAL INFORMATION NETWORK}

Until the year 1870, domestic telegraphy in Great Britain was run by private companies. The biggest of these were the Electric, the Magnetic and the United Kingdom Telegraph Company - the 'UK'. As can be seen in Table 3, together these three controlled more than 90 percent of the total domestic traffic in 1868.

\begin{tabular}{|c|c|c|}
\hline Company & Messages & $\%$ of Total \\
\hline Electric \& International & $3,137,478$ & 52.3 \\
\hline British \& Irish Magnetic & $1,530,961$ & 25.5 \\
\hline United Kingdom & 776,714 & 12.9 \\
\hline London \& Provincial & 183,304 & 3.1 \\
\hline Universal Private & 27,542 & 0.5 \\
\hline South Eastern Railway & 103,386 & 1.7 \\
\hline London Brighton Railway & 86,937 & 1.4 \\
\hline London Chatham Railway & 88,418 & 1.5 \\
\hline North British Railway & 51,032 & 0.9 \\
\hline Caledonian Railway & 16,262 & 0.3 \\
\hline Total & $6,002,034$ & 100 \\
\hline
\end{tabular}

Table 3. Number of inland messages forwarded by telegraph companies in the year 1868

Source: National Archives (NA), Post Office: Telegraphs, Post Office (Inland), POST 82/173, Estimates of revenues and expenditure under the Post Office with returns of staff, accounts, telegrams, offices, etc of Telegraph Companies.

The data arranged in Table 4 shows the average number of messages forwarded (i.e. as point of origin), received (i.e. as final destination) and transmitted (i.e. as intermediary station) in selected British cities during an average week in 1868. The London metropolitan area handled approximately three times the traffic of Manchester which comes second. Although we do not have data on the Magnetic's stations in Liverpool anymore, it seems likely that

${ }^{22}$ Wenzlhuemer, "The Development of Telegraphy, 1870-1900: A European Perspective on a World History Challenge.":1734 
Liverpool comes in third with an extrapolated quarter of London's traffic. These 'use' statistics clearly illustrate London's central role in the network. Not only did the capital generate a massive amount of traffic itself, it also served as the essential hub and switching station of the country transmitting 33,942 messages per week. Of these, an impressive 25,599 messages were handled by the Electric's Central Telegraph Station in Telegraph Street alone. ${ }^{23}$

\begin{tabular}{|c|c|c|c|c|c|}
\hline \multirow[t]{2}{*}{ City } & \multirow[t]{2}{*}{ Company } & \multicolumn{4}{|c|}{ Messages } \\
\hline & & Forwarded & Received & Transmitted & Total \\
\hline \multirow{3}{*}{ London } & Electric & 15,858 & 19,289 & 26,876 & 62,023 \\
\hline & Magnetic & 4,711 & 3,793 & 7,066 & 15,570 \\
\hline & Total & 20,569 & 23,082 & 33,942 & $\mathbf{7 7 , 5 9 3}$ \\
\hline \multirow{3}{*}{ Birmingham } & Electric & 418 & 43 & 30 & 490 \\
\hline & Magnetic & 432 & 540 & 1,012 & 1,984 \\
\hline & Total & 850 & 583 & 1,042 & 2,474 \\
\hline \multirow{3}{*}{ Brighton } & Electric & 617 & 633 & 636 & 1,886 \\
\hline & Magnetic & 94 & 162 & 0 & 256 \\
\hline & Total & 711 & 795 & 636 & 2,142 \\
\hline \multirow{3}{*}{ Bristol } & Electric & 812 & 751 & 1,500 & 3,063 \\
\hline & Magnetic & 259 & 479 & 55 & 793 \\
\hline & Total & 1,071 & 1,230 &, 555 & $\mathbf{3 , 8 5 6}$ \\
\hline \multirow{3}{*}{ Cardiff } & Electric & 648 & 595 & 1,310 & 2,553 \\
\hline & Magneti & 287 & 266 & 180 & 733 \\
\hline & Total & 935 & 861 & 1,490 & 3,286 \\
\hline \multirow{3}{*}{ Liverpool } & Electric & 4,101 & 3,856 & 1,691 & 9,648 \\
\hline & Magnetic & $\mathrm{n} / \mathrm{a}$ & $\mathrm{n} / \mathrm{a}$ & $\mathrm{n} / \mathrm{a}$ & $\mathrm{n} / \mathrm{a}$ \\
\hline & Total & 4,101 & 3,856 & 1,691 & 9,648 \\
\hline \multirow{3}{*}{ Manchester } & Electric & 5,011 & 3,941 & 3,735 & 12,687 \\
\hline & Magnetic & 5,076 & 3,712 & 4,342 & 13,130 \\
\hline & Total & 10,087 & 7,653 & $\mathbf{8 , 0 7 7}$ & 25,817 \\
\hline
\end{tabular}

Table 4. Average weekly number of messages transacted at all telegraph station in selected British cities, 1868.

Source: National Archives (NA), Post Office: Telegraphs, Private Companies, POST 81/51, POST 81/52, POST 81/53, POST 81/54, POST 81/55, Electric and International Telegraph Co Circuit returns. Post Office: Telegraphs, Private Companies, POST 81/12, POST 81/13, British and Irish Magnetic Telegraph Co Circuit Returns.

An analysis of the structure of the early twentieth-century telegraph network supports what the 'use' data tells us about London's high connectivity.

${ }^{23}$ National Archives (NA), Post Office: Telegraphs, Private Companies, POST 81/51, Electric and International Telegraph Co Circuit returns. 
Unfortunately, information on how exactly a certain node in the telegraph network was connected with other nodes is very rare and hard to come by. A map compiled by the International Telegraph Union in the year 1923, however, displays such data. The Carte Schematique des Grandes Communications Télégraphiques Internationales du Régime Européen" shows all direct telegraphic connections between cities and towns in Europe existing at the time. In order to allow for a thorough analysis, these connections have all been entered into a data matrix and analyzed with the help of the Social Network Analysis programme Ucinet for Windows, version $6.145 .^{24}$ The map only contains information for Europe and, thus, network connections beyond Europe have been truncated. While this naturally distorts some of the findings and generally downplays the importance of the nodes at or near the major cable landing sites, the data gained through the analysis should be accurate enough for our purposes. ${ }^{25}$

Four different network analysis measurements have been conducted with the raw data from the Carte Schematique which allow us to attach different attributes to the evaluated places. First, the Freeman degree centrality has been computed. This is one of the most widely used SNA centrality measures and simply counts the number of connections that a node maintains to other nodes. Valued data ${ }^{26}$ is recognised by this method, and therefore circuits with bigger transmission capacities are weighed higher. As can be seen in Table 5, London clearly has the highest number of direct connections with other places in Europe. Paris and Berlin come in second and third, but are outdistanced by the British capital. While the relatively simple degree measure informs us mainly about the number and capacity of existing connections, two other Freeman measures closeness and betweenness - are concerned with the actual position of a specific node in the network. ${ }^{27}$

Closeness is the reciprocal value of farness which in turn is the sum of all connections it takes for a node to reach each and every other node in the network. The higher its farness value, the less central is a certain node. The normalized closeness values (i.e. how many percent of the highest possible closeness value a

${ }^{24}$ Ucinet for Windows: Software for Social Network Analysis, Analytic Technologies, Cambridge, MA.

${ }^{25}$ The methods and results of the analysis have been explained in some greater detail in Wenzlhuemer, "The Dematerialization of Telecommunication: Communication Centres and Peripheries in Europe, 1850-1920."

${ }^{26}$ Valued data represents the different strengths of relations between network nodes. In our case, a connection comprised of several telegraph circuits has been weighed higher in the original data matrix than one made of only a single line. Some SNA methods do recognize such valued data, while others convert it to binary data.

${ }^{27}$ Linton Freeman, "Centrality in Networks: I. Conceptual Clarification," Social Networks 1, no. 3 (1979). _ , "The Gatekeeper, Pair-Dependency and Structural Centrality," Quality and Quantity 14 (1980). 
node reaches) are very close together for almost all 289 nodes in the network. Although Paris (2.311), Berlin (2.311) and London (2.305) lead the field, the differences between these places are not very pronounced. Milano, for instance, makes fifteenth and still has a normalized closeness of 2.285. While this tells us little about the relative centrality of the network nodes, it at least indicates that the European telegraph network of 1923 has been very tightly integrated.

The betweenness centrality measure, however, leaves us with an entirely different picture. This method shows how often the shortest connection between two nodes passes through the evaluated node and therefore indicates where a certain node is positioned in terms of the actual flow of information in the network. The normalized value is represented by nBetweenness. As can be seen in Table 6, Berlin, Paris and London end up very close together in this category and enjoy a comfortable lead against their pursuers.

\begin{tabular}{|r|l|r|}
\hline Node & Name & Degree \\
\hline 150 & London & 69 \\
\hline 195 & Paris & 58 \\
\hline 24 & Berlin & 50 \\
\hline 279 & Wien & 41 \\
\hline 44 & Budapest & 30 \\
\hline 5 & Amsterdam & 23 \\
\hline 73 & Danzig & 21 \\
\hline 113 & Hamburg & 21 \\
\hline 205 & Praha & 20 \\
\hline 8 & Anvers & 20 \\
\hline 42 & Bruxelles & 20 \\
\hline 214 & Rotterdam & 18 \\
\hline 161 & Malta & 17 \\
\hline 94 & Frankfurt & 16 \\
\hline 166 & Marseille & 15 \\
\hline-9
\end{tabular}

Table 5. Degree centrality of top fifteen network nodes.

Source: Bureau International des Administrations Télégraphiques, Carte Schematique des Grandes Communications Télégraphiques Internationales du Régime Européen dressée par le Bureau International de l'Union Télégraphique (Berne: Bureau International des Administrations Télégraphiques, 1923).

Software: Ucinet 6 for Windows

Remarks: The place names in the table resemble the language and spelling used in the original map. 
New Global Studies, Vol. 3 [2009], Iss. 1, Art. 2

\begin{tabular}{|r|l|r|r|}
\hline Node & Name & Betweenness & nBetweenness \\
\hline 24 & Berlin & 8434.273 & 20.408 \\
\hline 195 & Paris & 8296.616 & 20.075 \\
\hline 150 & London & 8204.229 & 19.852 \\
\hline 279 & Wien & 4983.795 & 12.059 \\
\hline 205 & Praha & 3462.52 & 8.378 \\
\hline 44 & Budapest & 3381.937 & 8.183 \\
\hline 113 & Hamburg & 2319.863 & 5.613 \\
\hline 96 & Fredericia & 2079.51 & 5.032 \\
\hline 73 & Danzig & 2018.054 & 4.883 \\
\hline 166 & Marseille & 1998.448 & 4.836 \\
\hline 104 & Gibraltar & 1956.103 & 4.733 \\
\hline 161 & Malta & 1716.444 & 4.153 \\
\hline 213 & Roma & 1659.672 & 4.016 \\
\hline 22 & Beograd & 1599.634 & 3.871 \\
\hline 254 & Thessaloniki & 1459 & 3.53 \\
\hline
\end{tabular}

Table 6. Betweenness centrality of top fifteen network nodes.

Source: Bureau International des Administrations Télégraphiques, Carte Schematique des Grandes Communications Télégraphiques Internationales du Régime Européen dressée par le Bureau International de l'Union Télégraphique (Berne: Bureau International des Administrations Télégraphiques, 1923).

Software: Ucinet 6 for Windows

Remarks: Data is symmetric and has been binarized for the calculation of betweenness.

The place names in the table resemble the language and spelling used in the original map.

\begin{tabular}{|c|c|c|c|c|c|}
\hline Node & Name & nDegree & nCloseness & nBetweenness & nEigenvector \\
\hline 195 & Paris & 11.458 & 2.311 & 20.075 & 49.974 \\
\hline 24 & Berlin & 11.111 & 2.311 & 20.408 & 45.439 \\
\hline 150 & London & 10.417 & 2.305 & 19.852 & 39.414 \\
\hline 279 & Wien & 10.417 & 2.301 & 12.059 & 34.743 \\
\hline 8 & Anvers & 4.861 & 2.291 & 0.982 & 30.808 \\
\hline 113 & Hamburg & 5.556 & 2.301 & 5.613 & 28.881 \\
\hline 205 & Praha & 5.903 & 2.304 & 8.378 & 28.817 \\
\hline 42 & Bruxelles & 4.861 & 2.29 & 1.586 & 28.446 \\
\hline 5 & Amsterdam & 4.514 & 2.29 & 1.099 & 28.032 \\
\hline 94 & Frankfurt & 4.167 & 2.291 & 1.098 & 27.411 \\
\hline 214 & Rotterdam & 4.167 & 2.289 & 2.435 & 26.077 \\
\hline 288 & Zürich & 4.167 & 2.292 & 2.413 & 22.689 \\
\hline 129 & Köln & 3.472 & 2.282 & 1.015 & 22.237 \\
\hline 44 & Budapest & 7.986 & 2.288 & 8.183 & 20.883 \\
\hline 178 & München & 4.167 & 2.291 & 3.103 & 20.063 \\
\hline
\end{tabular}

Table 7. Bonacich Eigenvector centrality of top fifteen network nodes.

Source: Bureau International des Administrations Télégraphiques, Carte Schematique des Grandes Communications Télégraphiques Internationales du Régime Européen dressée par le Bureau International de l'Union Télégraphique (Berne: Bureau International des Administrations Télégraphiques, 1923).

Software: Ucinet 6 for Windows

Remarks: Data is symmetric and has been binarized for all calculations including normalized Freeman degree.

The place names in the table resemble the language and spelling used in the original map. 
Table 7 displays the top fifteen European cities sorted according to their $n$ Eigenvector value. Bonacich's eigenvector method is the fourth measure used in our Social Network Analysis. ${ }^{28}$ Here a node is central, when it is connected to other central nodes. The table shows that London ranks third after Paris and Berlin in this category and still performs extremely well. Table 7 also rearranges the data from Tables 5 and 6 and illustrates that London is within the top three European cities in each and every category - usually with only minor distances to Paris and Berlin. While the available data is accurate enough to suggest that London has most definitely been among the three best connected cities in Europe in the year 1923, it is absolutely reasonable to assume that in reality London has occupied an even more central position. In all except the degree measure London's position suffers from the exclusive focus of the Carte Schematique on Europe. As has been pointed out earlier, the British capital held a crucial position as an entrepot for transatlantic telecommunication and enjoyed an excellent connectivity with South America, Africa and South Asia. The non-representation of these connections in the map certainly distorts the calculation and must be taken into account. As long as we are not able to work with a comprehensive circuit map of the entire globe, this analysis is as close as we will get to measuring European connectivity rates in the nineteenth and early twentieth century.

\section{LONDON'S INTERNAL CONNECTIVITY}

We have already established that both Great Britain as well as its capital London occupied central positions in the international telegraph network of the nineteenth and early twentieth century. We have also seen that London stood at the core of the British domestic network while other cities were relegated to less-connected positions. It is, therefore, absolutely justified to assume that Great Britain was not evenly developed in terms of network connectivity. Some regions - such as London or Manchester - maintained more and better connections than the provincial backwaters. But can we find similarly asymmetrical connectivity patterns within nineteenth-century London as well?

In order to answer this question, circuit data for all Electric, Magnetic and UK telegraph stations in London has been entered into a matrix and evaluated with Ucinet for Windows. Together with other structural and flow data, the results from the Social Network Analysis have than been brought into relation with demographic and geographical data on London in order to make the information

\footnotetext{
28 Phillip Bonacich, "Factoring and Weighting Approaches to Status Scores and Clique Identification," Journal of Mathematical Sociology 2 (1972).
} 
comparable and meaningful. ${ }^{29}$ Whenever possible I have tried to visualise the results with the help of Historical GIS methods and the open source programmes MapWindow GIS, version 4.3.2559 $9^{30}$ and fGIS, version 2005.09.13. ${ }^{31}$

Table 8 displays the amount of handled messages within a registration district in relation to the population and the area of the district. The figures on population and district size have been taken from the 1871 census data contained in the UKBORDERS set for London of the same year. ${ }^{32}$ It can easily be seen that the London City registration district has by far the highest amount of information flow - in absolute terms as well as in relation to the inhabitants and the size of the district. The gap to the districts Strand and Westminster, which rank second and third, is so pronounced that no reasonable competition exists. The City handles more than 85 percent of the total telegraph traffic of London. The Strand and Westminster only account for 2.69 percent and 1.49 percent of the traffic respectively. Figure 4 visualises these results and shows that some of the more central districts such as Strand, Westminster, St. Giles, Stepney or Marylebone exhibit at least a modest flow of information, while the remoter districts see hardly any traffic at all (as can be seen from the different shades). The map also shows the high concentration of telegraph stations in the central districts and especially in the City. Figure 5 zooms in on the city centre and depicts the locations of telegraph stations by giving their names and the average traffic handled per week. It is absolutely evident that the City of London housed most of the major metropolitan telegraph stations (including all the big companies' central stations at Central, Threadneedle Street and Gresham House). Another cluster of stations is visible around the district of Westminster, but - as Table 8 signifies its throughput in terms of messages handled is marginal compared to the City.

\footnotetext{
${ }^{29}$ Please note that the demographic data used here comes from the Census of 1871 , while the circuit data is of the year 1868 .

${ }^{30}$ Mapwindow Gis: Open Source Programmable Geographic Information System Tools Ver. 4.3.2559, Idaho State University, Pocatello.

${ }^{31}$ Forestry Gis (Fgis) Ver. 2005.09.13, University of Wisconsin.

${ }^{32}$ UKBORDERS England Registration Districts 1871, available from EDINA, Map and Data Place, UKBORDERS. http://www.edina.ac.uk/ukborders.

Unfortunately it has at some occasions been unclear in which districts a particular station was located as the exact location (for instance where exactly in a certain street) was sometimes difficult to find out. In such cases the stations have received a GPS tag containing their longitude and latitude that came as close as possible to their actual position. Together with other minor inaccuracies in the synchronisation of the station GPS data and the GIS border set for London in 1871, this has led to a few instances where it remained unclear to which district a particular station belonged. In all such cases, I have decided to refer to the synchronised GIS map as the sole authority. This means that if a station falls into a certain district in our map - no matter how close to the district border - it has been treated as such. The most notable example is the station Holborn (UK), which has not been counted as belonging to the registration district with the same name, but rather as falling into the City of London.
} 
Wenzlhuemer: London in the Global Telecommunication Network of the Nineteenth Century

\begin{tabular}{|c|c|c|c|c|c|c|c|c|}
\hline No & Registration District & $\begin{array}{l}\text { Population } \\
1871\end{array}$ & $\begin{array}{l}\text { Area } \\
1871\end{array}$ & $\begin{array}{l}\text { Pop. } \\
\text { Density }\end{array}$ & $\begin{array}{l}\text { Weekly } \\
\text { Mess. }\end{array}$ & $\begin{array}{l}\% \text { of } \\
\text { Total }\end{array}$ & $\begin{array}{c}\text { Mess. } \\
\text { per } \\
\text { Head }\end{array}$ & $\begin{array}{c}\text { Mess. } \\
\text { per Area }\end{array}$ \\
\hline 1 & Lambeth & 208,342 & 3,941 & 53 & 856 & 1.00 & 0.0041 & 0.2172 \\
\hline 2 & Camberwell & 111,306 & 4,450 & 25 & 0 & 0.00 & 0.0000 & 0.0000 \\
\hline 3 & Lewisham & 51,557 & 11,436 & 5 & 0 & 0.00 & 0.0000 & 0.0000 \\
\hline $4 \vdots$ & St. George Hanover Sq & 221,986 & 2,758 & 80 & 1,084 & 1.26 & 0.0049 & 0.3930 \\
\hline 5 & St. Saviour Southwark & 175,049 & 1,119 & 156 & 755 & 0.88 & 0.0043 & 0.6747 \\
\hline 6 & St. Olave Southwark & 122,398 & 1,503 & 81 & 0 & 0.00 & 0.0000 & 0.0000 \\
\hline 7 & Greenwich & 93,233 & 2,769 & 34 & 0 & 0.00 & 0.0000 & 0.0000 \\
\hline 8 & Woolwich & 75,245 & 7,250 & 10 & 12 & 0.01 & 0.0002 & 0.0017 \\
\hline 9 & Pancras & 221,465 & 2,672 & 83 & 839 & 0.98 & 0.0038 & 0.3139 \\
\hline 10 & Hampstead & 32,281 & 2,248 & 14 & 0 & 0.00 & 0.0000 & 0.0000 \\
\hline 11 & Poplar & 115,932 & 2,335 & 50 & 243 & 0.28 & 0.0021 & 0.1040 \\
\hline 12 & Islington & 213,778 & 3,107 & 69 & 884 & 1.03 & 0.0041 & 0.2846 \\
\hline 13 & Hackney & 134,792 & 4,573 & 29 & 0 & 0.00 & 0.0000 & 0.0000 \\
\hline 14 & Strand & 64,345 & 509 & 126 & 2,307 & 2.69 & 0.0359 & 4.5324 \\
\hline 15 & London City & 75,208 & 648 & 116 & 73,145 & 85.16 & 0.9726 & 112.8781 \\
\hline 16 & Whitechapel & 76,273 & 365 & 209 & 0 & 0.00 & 0.0000 & 0.0000 \\
\hline 17 & Marylebone & 159,254 & 1,506 & 106 & 835 & 0.97 & 0.0052 & 0.5544 \\
\hline 18 & Shoreditch & 127,164 & 648 & 196 & 205 & 0.24 & 0.0016 & 0.3165 \\
\hline 19 & Mile End O.T. & 92,841 & 679 & 137 & 0 & 0.00 & 0.0000 & 0.0000 \\
\hline 20 & Bethnal Green & 120,104 & 755 & 159 & 468 & 0.54 & 0.0039 & 0.6199 \\
\hline 21 & Westminster & 51,181 & 216 & 237 & 1,280 & 1.49 & 0.0250 & 5.9259 \\
\hline 22 & St. Giles & 53,556 & 245 & 219 & 676 & 0.79 & 0.0126 & 2.7592 \\
\hline 23 & St. George in the East & 48,052 & 243 & 198 & 0 & 0.00 & 0.0000 & 0.0000 \\
\hline 24 & Chelsea & 142,178 & 1,592 & 89 & 407 & 0.47 & 0.0029 & 0.2557 \\
\hline 25 & Wandsworth & 127,769 & 12,167 & 11 & 59 & 0.07 & 0.0005 & 0.0048 \\
\hline 26 & Stepney & 57,690 & 462 & 125 & 680 & 0.79 & 0.0118 & 1.4719 \\
\hline 27 & Kensington & 337,411 & 5,631 & 60 & 1,075 & 1.25 & 0.0032 & 0.1909 \\
\hline 28 & Holborn & 219,246 & 1,174 & 187 & 77 & 0.09 & 0.0004 & 0.0656 \\
\hline
\end{tabular}

Table 8. Population, area and average weekly messages in London registration districts 1868/1871.

Source: National Archives (NA), Post Office: Telegraphs, Private Companies, POST 81/51, POST 81/52, POST 81/53, POST 81/54, POST 81/55, Electric and International Telegraph Co Circuit returns. Post Office: Telegraphs, Private Companies, POST 81/12, POST 81/13, British and Irish Magnetic Telegraph Co Circuit Returns; Post Office: Telegraphs, Private Companies, POST 81/77, United Kingdom Electric Telegraph Company, Circuit returns from offices in the metropolitan, English and Scottish districts.

Census data from Population Census 1871 as contained in UKBORDERS England Registration Districts 1871, available from EDINA, Map and Data Place, UKBORDERS. http://www.edina.ac.uk/ukborders. 
New Global Studies, Vol. 3 [2009], Iss. 1, Art. 2

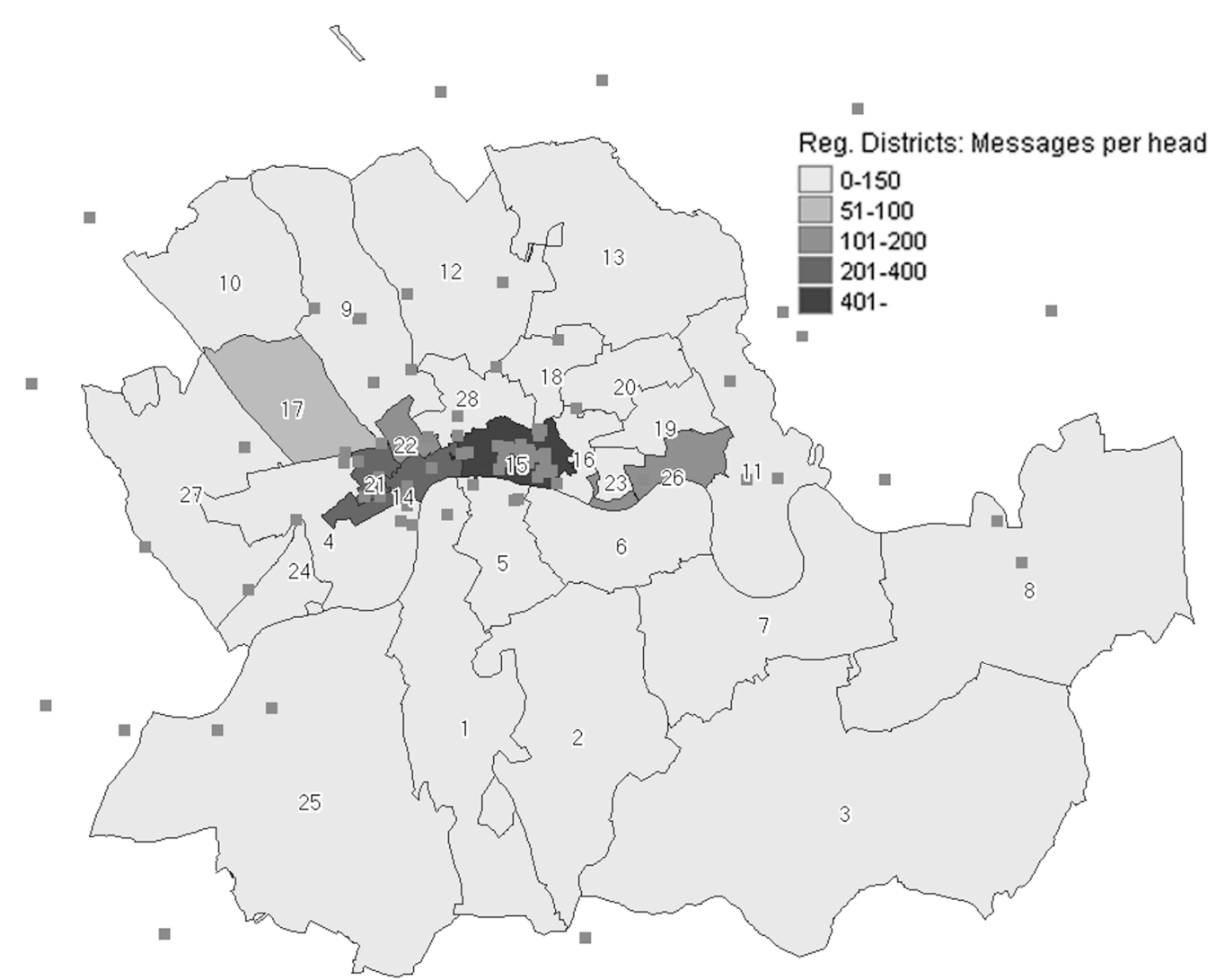

Figure 4. Average weekly messages per head in London registration districts 1868/71 and location of metropolitan telegraph stations 1868.

Source: National Archives (NA), Post Office: Telegraphs, Private Companies, POST 81/51, POST 81/52, POST 81/53, POST 81/54, POST 81/55, Electric and International Telegraph Co Circuit returns. Post Office: Telegraphs, Private Companies, POST 81/12, POST 81/13, British and Irish Magnetic Telegraph Co Circuit Returns; Post Office: Telegraphs, Private Companies, POST 81/77, United Kingdom Electric Telegraph Company, Circuit returns from offices in the metropolitan, English and Scottish districts.

GIS Border sets and census data from Population Census 1871 as contained in UKBORDERS England Registration Districts 1871, available from EDINA, Map and Data Place, UKBORDERS. http://www.edina.ac.uk/ukborders.

Created with MapWindow GIS, version 4.3.2559.

Note: $\quad$ Registration district numbers correspond with Table 8. 
Wenzlhuemer: London in the Global Telecommunication Network of the Nineteenth Century

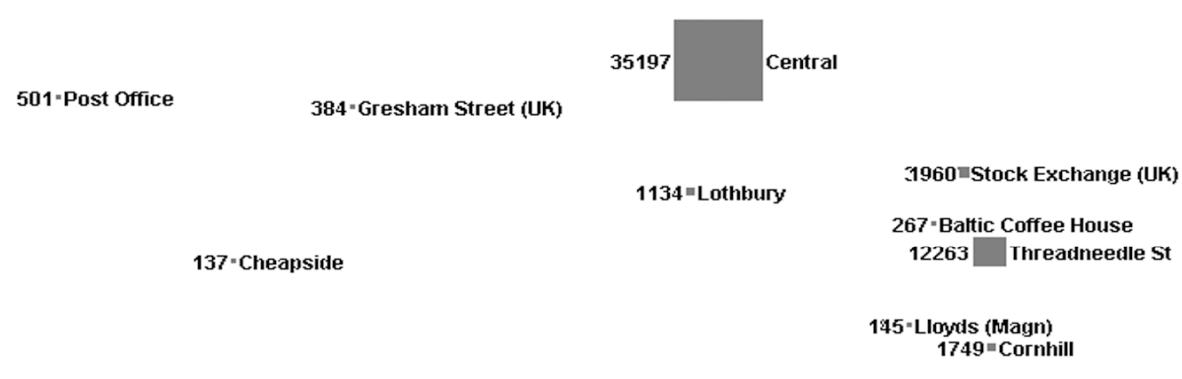

309-Cannon Street (UK)

128-Upper Thames St

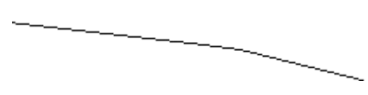

Figure 5. Telegraph stations in the City of London and the number of total messages handled per week, 1868 . Source: see Figure 4.

Published by The Berkeley Electronic Press, 2009 
New Global Studies, Vol. 3 [2009], Iss. 1, Art. 2

\begin{tabular}{|c|c|c|c|}
\hline Node & Station & Degree & nDegree \\
\hline 63 & Central & 293 & 6.123 \\
\hline 242 & Shoreditch & 118 & 2.466 \\
\hline 263 & Stratford & 89 & 1.860 \\
\hline 289 & Waterloo & 60 & 1.254 \\
\hline 273 & Threadneedle St (Magn) & 57 & 1.191 \\
\hline 123 & Gresham House (UK) & 50 & 1.045 \\
\hline 105 & Euston & 42 & 0.878 \\
\hline 71 & Clapham Junction & 32 & 0.669 \\
\hline 298 & Willesden & 25 & 0.522 \\
\hline 86 & Dalston & 24 & 0.502 \\
\hline 32 & Bow & 21 & 0.439 \\
\hline 5 & Angel Road & 20 & 0.418 \\
\hline 54 & Camden Road & 20 & 0.418 \\
\hline 64 & Chalk Farm & 20 & 0.418 \\
\hline 275 & Tottenham & 18 & 0.376 \\
\hline 53 & Camden & 17 & 0.355 \\
\hline 45 & Broad Street & 16 & 0.334 \\
\hline 10 & Barnes & 14 & 0.293 \\
\hline 151 & Kensington & 14 & 0.293 \\
\hline 153 & Kings Cross & 13 & 0.272 \\
\hline 133 & Highbury & 12 & 0.251 \\
\hline 9 & Barking & 10 & 0.209 \\
\hline 245 & Snaresbrook & 10 & 0.209 \\
\hline 259 & Stock Exchange & 10 & 0.209 \\
\hline 300 & Wimbledon & 10 & 0.209 \\
\hline
\end{tabular}

Table 9. Degree centrality of top twenty-five London telegraph stations, 1868.

Source: National Archives (NA), Post Office: Telegraphs, Private Companies, POST 81/51, POST 81/52, POST 81/53, POST 81/54, POST 81/55, Electric and International Telegraph Co Circuit returns. Post Office: Telegraphs, Private Companies, POST 81/12, POST 81/13, British and Irish Magnetic Telegraph Co Circuit Returns; Post Office: Telegraphs, Private Companies, POST 81/77, United Kingdom Electric Telegraph Company, Circuit returns from offices in the metropolitan, English and Scottish districts.

Software: Ucinet 6 for Windows

The structural data from the network analysis generally supports the findings of these 'use' statistics. For our purposes, only those circuits have been computed which had at least one end in the capital. Tables 9-11 display the results of the four SNA measures conducted and in each case list the top twentyfive London network nodes. A look at the degree figures in Table 9 reveals that four telegraph stations worked by the Electric or by railway companies aligned with the Electric lead the table in terms of the highest number of connections maintained with other stations - Central, Shoreditch, Stratford and Waterloo. With a normalised degree of 6.123, Central has 2.5 times more connections than Shoreditch which ranks second. The Magnetic and UK headquarters at 
Threadneedle Street and Gresham House only come fifth and sixth with normalised degrees of slightly more than one percent. Interestingly, only the three headquarters and the stations at Broad Street and the Stock Exchange maintain enough direct connections to make it into the top twenty-five of a total of 92 bureaus in London. Many of the other stations in the table serve as terminals for the railway lines radiating from London. The closeness measure in Table 10 gives a similar picture - with the remarkable peculiarity that only Electric stations (and the Magnetic headquarter at Threadneedle Street) can be found in the top list as the Electric network has been far larger then those of the competitors. This naturally favours the Electric, when it comes to measuring how easy all other stations could be reached from a certain node. Apart from this, the Electric headquarter and the railway terminals and key stations rank highest, while important City bureaus at the Coal and Stock Exchange slowly start to reveal their centrality by climbing up the list. The betweenness measure provides us with a picture similar to the degree computation. Again, the headquarters and the terminals of the railway spoke lines are most likely to serve as intermediary stations in the information flow. The figures in Table 11 clearly emphasise the important role of the three headquarters as relay stations and switches. Hardly any useful connections could have been made without passing through one of these three offices. Finally, there is the eigenvector measure as seen in Table 12. Here we do not find any non-Electric stations among the top twenty-five. Indeed, Threadneedle Street marks the first appearance of a Magnetic or UK bureau at rank 48. Again, stations closely connected with Central as well as with the stations on the railway spokes perform best. Together with the offices at Westminster, the Coal Exchange and the Stock Exchange - all of which maintain very tight links with Central - these bureaus are closest to the actual information flow (the biggest part of which came via the Electric network). 


\begin{tabular}{|c|c|c|c|}
\hline Node & Station & Farness & nCloseness \\
\hline 63 & Central & 508 & 62.795 \\
\hline 273 & Threadneedle St (Magn) & 692 & 46.098 \\
\hline 263 & Stratford & 770 & 41.429 \\
\hline 289 & Waterloo & 771 & 41.375 \\
\hline 242 & Shoreditch & 773 & 41.268 \\
\hline 71 & Clapham Junction & 774 & 41.214 \\
\hline 151 & Kensington & 789 & 40.431 \\
\hline 32 & Bow & 797 & 40.025 \\
\hline 300 & Wimbledon & 799 & 39.925 \\
\hline 105 & Euston & 800 & 39.875 \\
\hline 9 & Barking & 803 & 39.726 \\
\hline 45 & Broad Street & 804 & 39.677 \\
\hline 86 & Dalston & 804 & 39.677 \\
\hline 298 & Willesden & 804 & 39.677 \\
\hline 53 & Camden & 806 & 39.578 \\
\hline 243 & Shoreditch Street Office & 810 & 39.383 \\
\hline 64 & Chalk Farm & 816 & 39.093 \\
\hline 153 & Kings Cross & 817 & 39.045 \\
\hline 54 & Camden Road & 818 & 38.998 \\
\hline 219 & Paddington & 818 & 38.998 \\
\hline 85 & Crystal Palace & 820 & 38.902 \\
\hline 72 & Coal Exchange & 821 & 38.855 \\
\hline 133 & Highbury & 821 & 38.855 \\
\hline 259 & Stock Exchange & 821 & 38.855 \\
\hline 287 & War Office & 821 & 38.855 \\
\hline
\end{tabular}

Table 10. Closeness centrality of top twenty-five London telegraph stations, 1868. Source: Table 9 
Wenzlhuemer: London in the Global Telecommunication Network of the Nineteenth Century

\begin{tabular}{|r|l|r|r|}
\hline Node & Station & Betweenness & nBetweenness \\
\hline 63 & Central & $44,716.094$ & 88.161 \\
\hline 273 & Threadneedle St (Magn) & $13,589.500$ & 26.793 \\
\hline 123 & Gresham House (UK) & $11,934.500$ & 23.530 \\
\hline 263 & Stratford & $3,588.995$ & 7.076 \\
\hline 289 & Waterloo & $3,284.234$ & 6.475 \\
\hline 242 & Shoreditch & $2,388.231$ & 4.709 \\
\hline 71 & Clapham Junction & $2,032.724$ & 4.008 \\
\hline 151 & Kensington & $1,917.386$ & 3.780 \\
\hline 10 & Barnes & 975.033 & 1.922 \\
\hline 153 & Kings Cross & 952.500 & 1.878 \\
\hline 105 & Euston & 493.426 & 0.973 \\
\hline 5 & Angel Road & 321.750 & 0.634 \\
\hline 85 & Crystal Palace & 320.750 & 0.632 \\
\hline 3 & Admiralty & 318.500 & 0.628 \\
\hline 261 & Stock Exchange (UK) & 318.500 & 0.628 \\
\hline 96 & Edgware Road & 318.000 & 0.627 \\
\hline 262 & Strand & 318.000 & 0.627 \\
\hline 287 & War Office & 316.500 & 0.624 \\
\hline 310 & Woolwich Arsenal & 316.500 & 0.624 \\
\hline 298 & Willesden & 144.964 & 0.286 \\
\hline 53 & Camden & 122.193 & 0.241 \\
\hline 32 & Bow & 52.281 & 0.103 \\
\hline 45 & Broad Street & 14.562 & 0.029 \\
\hline 86 & Dalston & 12.657 & 0.025 \\
\hline 64 & Chalk Farm & 10.717 & 0.021 \\
\hline
\end{tabular}

Table 11. Betweenness centrality of top twenty-five London telegraph stations, 1868.

Source: Table 9 


\begin{tabular}{|r|l|r|r|}
\hline Node & Station & Eigenvec & nEigenvec \\
\hline 242 & Shoreditch & 0.542 & 76.667 \\
\hline 63 & Central & 0.416 & 58.831 \\
\hline 263 & Stratford & 0.347 & 49.012 \\
\hline 86 & Dalston & 0.087 & 12.242 \\
\hline 32 & Bow & 0.083 & 11.779 \\
\hline 5 & Angel Road & 0.079 & 11.199 \\
\hline 275 & Tottenham & 0.079 & 11.167 \\
\hline 45 & Broad Street & 0.074 & 10.405 \\
\hline 289 & Waterloo & 0.071 & 10.026 \\
\hline 105 & Euston & 0.070 & 9.933 \\
\hline 264 & Stratford Bridge & 0.055 & 7.736 \\
\hline 204 & North Woolwich & 0.052 & 7.352 \\
\hline 9 & Barking & 0.049 & 6.989 \\
\hline 64 & Chalk Farm & 0.042 & 5.971 \\
\hline 54 & Camden Road & 0.042 & 5.903 \\
\hline 72 & Coal Exchange & 0.037 & 5.240 \\
\hline 219 & Paddington & 0.035 & 4.991 \\
\hline 262 & Strand & 4.960 \\
\hline 250 & Southwark & 0.035 & 4.960 \\
\hline 295 & Westminster & 0.034 & 4.863 \\
\hline 298 & Willesden & 0.034 & 4.863 \\
\hline 259 & Stock Exchange & 0.032 & 4.473 \\
\hline 300 & Wimbledon & 0.032 & 4.457 \\
\hline 133 & Highbury & 4.366 \\
\hline 71 & Clapham Junction & 0.031 & 4.068 \\
\hline & 0.027 & 3.835 \\
\hline
\end{tabular}

Table 12. Eigenvector centrality of top twenty-five London telegraph stations, 1868. Source: Table 9

The network analysis, therefore, mostly supports the results of our earlier use and traffic analysis, but also highlights the important position of the railway terminals in London. While the City of London and the telegraph bureaus situated therein exhibit by far the highest traffic within the metropolitan area (indeed within the entire United Kingdom), the picture is more diversified if we look at the centrality of certain stations and districts. The City is still the individually most important core of the network as it houses all three company headquarters as well as the coal and stock exchanges. Yet it has become very clear that the railway terminals occupy crucial positions in the flow of information in and out of the capital. The offices at stations such as Shoreditch (Great Eastern), Euston (London \& North Western) or Waterloo (London \& South Western) are prime 
examples for this diversification, but still they are located comparatively near the city centre. While the City of London together with contributions from the West End generated the biggest amount of information communicated (pretty much like today), important switches and relay stations were often located at the fringes of the actual city centre.

\section{CONCLUSION}

As a look at the Submarine Cable Map 2007 reveals, global connectivity is not evenly distributed around the world. While international cable connections are particularly tight around North America, Europe or East and South-East Asia, other regions of the world - such as Africa, Central Asia or Latin America - have been largely overlooked in this regard. Representations that focus on telecommunication use rather than structures show an even greater divide between world regions. Data collected and assembled by the Information Technology and International Cooperation programme clearly demonstrates that most African, Asian (including the structurally well-connected states of East and South-East Asia) and Latin American countries exhibited only marginal internet use rates in the year 2005..$^{33}$ A global digital divide still separates the connected from the unconnected. And a similar divide exists within countries or - as we have seen in the London example - within generally well-positioned cities as well.

While it has been suggested that these various divides will soon be closed due to the proliferation of cheap information technology, ${ }^{34}$ historical evidence does not support this view. On the contrary, we have seen how similar global connectivity patterns of the late nineteenth century are to current ones, how the United Kingdom and London have managed to secure central positions in the global web despite the rapidly changing geopolitical situation after decolonisation and how London's internal connectivity gap still largely resembles that of the 1860s. All this supports the notion that uneven connectivity patterns tend to persist due to their being products as well as constituents of complex social practices (Thrift). They built on a socioeconomic and cultural basis that informs a big part of their inner rationale. Therefore, rapid technological progress rarely directly translates into structural network changes. On the other hand, the step-bystep evolution of network technologies can have a persisting influence on the network structure in times of fast socioeconomic change.

\footnotetext{
${ }^{33}$ The Information Technology and International Cooperation programme can be found at the website of the Social Science Research Council at http://programs.ssrc.org/itic/itst/. The data has been visualised in a map available at

http://www.govcom.org/maps/map_set_wsis/GC0_Maps_set_3.0_digitaldivide.pdf.

${ }^{34}$ Benjamin M. Compaine, The Digital Divide : Facing a Crisis or Creating a Myth? (Cambridge, MA ; London: MIT Press, 2001).
} 
Examining global connectivity patterns of the nineteenth century and their interaction with the social, economic and cultural development of their carrier societies can, therefore, serve as a historical laboratory in which we can ask questions and test hypotheses which eventually revolve around current problems but cannot be fully answered from a current perspective. To this end, more information on nineteenth-century network structure or information flow patterns will be needed. It is, therefore, hoped that future studies might take up the approach of this paper and contribute to the broadening of the data base.

\section{REFERENCES}

Bonacich, Phillip. "Factoring and Weighting Approaches to Status Scores and Clique Identification." Journal of Mathematical Sociology 2, (1972): 11320.

Ucinet for Windows: Software for Social Network Analysis. Analytic Technologies, Cambridge, MA.

Forestry Gis (Fgis) Version 2005.09.13. University of Wisconsin.

Bureau International des Administrations Télégraphiques. "Nomenclature Des Cables Formant Le Réseau Sous-Marin De Globe." Journal Télégraphique III, no. 29 (1877).

Compaine, Benjamin M. The Digital Divide : Facing a Crisis or Creating a Myth? Cambridge, MA ; London: MIT Press, 2001.

Cook, Gary, Naresh Pandit, Jonathan Beaverstock, Peter Taylor, and Kathy Pain. "The Role of Location in Knowledge Creation and Diffusion: Evidence of Centripetal and Centrifugal Forces in the City of London Financial Services Agglomeration." Environment and Planning A 39, no. 6 (2007): 1325-45.

Ferguson, Niall. The House of Rothschild. The World's Bankers, 1849-1999 New York: Viking, 1999.

Freeman, Linton. "Centrality in Networks: I. Conceptual Clarification." Social Networks 1, no. 3 (1979): 215-39. 
Wenzlhuemer: London in the Global Telecommunication Network of the Nineteenth Century

_. "The Gatekeeper, Pair-Dependency and Structural Centrality." Quality and Quantity 14, (1980): 585-92.

Graham, Stephen, and Simon Marvin. Splintering Urbanism : Networked Infrastructures, Technological Mobilites and the Urban Condition. London: Routledge, 2001.

Hughes, Thomas. "The Evolution of Large Technological Systems." In The Social Construction of Technological Systems, edited by Wiebe Bijker, Thomas Hughes and Trevor Pinch, 51-82. Cambridge, MA: MIT Press, 1993.

International Telegraph Bureau. "Chart of the World's Principal International Cables." Berne: International Telegraph Bureau, 1924.

Mapwindow Gis: Open Source Programmable Geographic Information System Tools Version 4.3.2559. Idaho State University, Pocatello.

Odlyzko, Andrew. "History of Communications and Its Implications for the Internet ": AT\&T Labs, 2000.

Rutherford, Jonathan. "Networks in Cities, Cities in Networks: Territory and Globalisation Intertwined in Telecommunications Infrastructure Development in Europe." Urban Studies 42, no. 13 (2005): 2389-406.

- A Tale of Two Global Cities : Comparing the Territorialities of Telecommunications Developments in Paris and London. Aldershot: Ashgate, 2004.

Taylor, Peter, and Rolee Aranya. "Connectivity and City Revival." Town \& Country Planning 75, no. 11 (2006): 309-14.

_. "A Global 'Urban Roller Coaster'? Connectivity Changes in the World City Network, 2000-04." GaWC Study Group, Loughborough University, http://www.lboro.ac.uk/gawc/rb/rb192.html.

TeleGeography. "Map of European City Connectivity." Primetrica, Inc., http://www.telegeography.com/ee/free resources/figures/ib-05.php.

__. "Submarine Cable Map 2007." Primetrica, Inc., http://www.telegeography.com/products/map cable/index.php. 
Thrift, Nigel. "New Urban Eras and Old Technological Fears: Reconfiguring the Goodwill of Electronic Things." Urban Studies 33, no. 8 (1996): 1463-93.

Walker, David, and Peter Taylor. "Atlas of Economic Clusters in London." GaWC Study Group, Loughborough University, http://www.lboro.ac.uk/gawc/visual/lonatlas.html.

Wenzlhuemer, Roland. "The Dematerialization of Telecommunication: Communication Centres and Peripheries in Europe, 1850-1920." Journal of Global History 2, no. 3 (2007): 345-72.

—. "The Development of Telegraphy, 1870-1900: A European Perspective on a World History Challenge." History Compass 5, no. 5 (2007): 172042. 